\title{
Evaluation of a site conservation rating system in southeastern Arizona
}

\author{
SUSAN E. WATTERS, MARK A. WELTZ, AND E. LAMAR SMITH
}

\begin{abstract}
Authors are extension 4-H youth development agent, 450 Haskell, Willcox, AZ \$5643, hydrologist, USDA-ARS 2000 E. Allen Rd., Tucson, Ariz. 85719, and associate professor, Range Management, University of Arizona, Tucson, AZ 85721. At the time of the research, the senior author was a graduate student, Range Management Program, University of Arizona.
\end{abstract}

\begin{abstract}
The objectives of this study were to identify a Site Conservation Threshold, the point at which accelerated erosion occurs, and to examine the usefulness of the Water Erosion Prediction Project (WEPP) model in determining the Site Conservation Threshold on a clay loam upland rangeland site. Sixteen sample sites were chosen to represent a wide range of species composition, ground cover, biomass and apparent soil stability to determine which of these factors could be used to evaluate the site conservation status of a clay-loam upland ecological site on a southern Arizona semi-arid desert grassland. A Site Stability Rating based on observable vegetation and soil-surface characteristics (i.e. ground surface cover and distribution of plants) was developed. A Site Stability Rating was estimated for 100 quadrats per sample site and averaged for the entire sample site. The Water Erosion Prediction Project model was used as an objective index of soil stability to assess the degree of site protection. The Soil Conservation Service soil loss tolerance value (T) was used with the sediment yield predicted by the WEPP model to establish a threshold value for the Site Stability Rating. The objective measures of standing biomass, basal cover, average distance to the nearest perennial plant, and frequency of quadrats with no rooted perennial plant showed strong relationships to the subjective Site Stability Rating. Site Conservation Thresholds were identified for standing biomass $(750 \mathrm{~kg} / \mathrm{ha})$, basal cover $(8 \%)$, average distance to the nearest perennial plant $(15 \mathrm{~cm})$, and frequency of quadrats $(20 \times 20 \mathrm{~cm})$ with no rooted perennial plant $(13 \%)$.
\end{abstract}

Key Words: range condition, soil erosion, site conservation, sustainable agriculture, threshold, WEPP model

Definitions of rangeland condition and use of the concept vary among agencies, but historically rangeland condition assessment has been based upon vegetation, climax-based or productivity-based (Smith 1989). Both approaches depend on assessment in relation to the potential or capability of the ecologi-

The authors would like to thank the Environmental Protection Agency Rangeland Environmental Mapping and Assessment Program for funding a portion of this project through an interagency agreement with the USDA-Agriculture Research Service. Additional support provided by USDA-Hatch Funds and the State of Arizona.

Manuscript accepted 8 Jul 1995. cal site and on the amount and composition of the vegetation (Smith 1988). A separate evaluation for soil and vegetation condition has been recommended since a site cannot be expected to continue to maintain maximum vegetation production if it has accelerated erosion (USDI-BLM 1993, Ellison 1949, NRC 1994, SRM 1983 and 1991). Accelerated erosion has been defined as "an increase in the rate of erosion that is the result of land use and/or management, and which significantly increases the rate or probability of loss of site potential from these influences" (SRM 1991, p. 13). Soil erosion is a natural process, but the quantity and rate of surface runoff and sediment yield may be altered through land use and management practices (Blackburn et al. 1982, Gifford and Hawkins 1978, Thurow et al. 1986, Weltz and Wood 1986).

The Committee on Rangeland Classification (NRC 1994, p. 4) defines rangeland health "as the degree to which the integrity of the soil and the ecological processes of rangeland ecosystems are sustained." They recommend the determination of rangeland health should be based on the evaluation of 3 criteria: degree of soil stability and watershed function, integrity of nutrient cycles and energy flows, and the presence of functioning recovery mechanisms. The SRM (1991) proposed a site conservation rating to assess the degree of protection from erosion afforded a site. The major recommendation of the SRM (1991) was: "The effectiveness of present vegetation in protecting the site against accelerated erosion by water and/or wind should be assessed independently of the actual or proposed use of the site. This assessment should be called a Site Conservation Rating. The Site Conservation Rating at which accelerated erosion begins should be called the Site Conservation Threshold. Any site rated below the Site Conservation Threshold would be considered in unsatisfactory condition and those above it, satisfactory." The difficulty in rating an area arises in identifying the thresholds that allow an area to move from one category to another (USDI-BLM 1993).

Attempts have been made to establish soil cover guidelines required for site protection. Packer (1951) found ground cover the most influential in affecting overland flow on steep slopes, and soil erosion was most affected by the size of maximum bare openings. He suggested $70 \%$ cover was required for adequate protection (would depend upon frequency and intensity of rainfall). Orr (1970) concluded that plant and litter cover must be greater than $60 \%$ for maximum soil stability in the Black Hills of South Dakota. Gifford (1984) suggested that $50-60 \%$ cover is probably sufficient. Although many studies have identified mini- 
mum cover values in the 60-75\% range (Costin 1980, Lang 1979, Marston 1952, Noble 1965), Moore et al. (1979) speculated that a minimum cover value of $20 \%$ may be sufficient in controlling runoff and surface erosion in Kenya. Costin et al. (1960) reported the cover should be near 100\% for some Australian conditions. Gifford (1984) found that various cover types (vegetation, litter, rock, and erosion pavement) offer differing degrees of soil protection, and the effectiveness of the different cover types vary with time of year and within a given storm.

This study is based upon the concepts proposed by the SRM (1991) to define techniques of establishing the condition of our nation's rangelands. Our objectives were 1) to develop criteria for the evaluation and establishment of Site Conservation Thresholds on a clay loam upland site and 2) to evaluate the usefulness of the Water Erosion Prediction Project (WEPP) model (Lane and Nearing 1989) in determining the Site Conservation Threshold. It is hypothesized that rangelands that rill with a 10 -year return period event are unsustainable. Rangelands that initiate rilling with the 25-year return period event are at risk to degradation and that rangelands that do not initiate rilling until the 50-year return period event are potentially sustainable.

\section{Study Area and Methods}

The study area is an alluvial terrace located $27 \mathrm{~km}$ west of Willcox, Arizona in the Major Land Resource Area, 41-3, Chihuahuan Semi-desert Grassland (USDA-SCS 1988). Long term (30 years) average annual precipitation in Willcox is 293 $\mathrm{mm}$, with an average growing season precipitation of $197 \mathrm{~mm}$ (NOAA 1991). The area has a 3 to $4 \%$ slope, with an average elevation of $1,500 \mathrm{~m}$. The study area is classified as a clay loam upland ecological site (USDA-SCS 1988). The Whitehouse soil series found on the site is deep and well drained, with high available water capacity, slow permeability, slow to medium nunoff, and moderate hazard of erosion (Hendricks 1985). In this semiarid region of the Southwest, annual above-ground net primary productivity can vary from 500 to $1,350 \mathrm{~kg} / \mathrm{ha}$ on this rangeland site (USDA-SCS 1988). The current vegetation is dominated by warm season perennial grasses such as Hilaria mutica (Buckl.) Benth. (tobosa), Hilaria belangeri (Steud.) Nash. (curly mesquite), Bouteloua curtipendula (Michx.) Torr. (sideoats grama), Bouteloua eriopoda Torr. (black grama), and Aristida spp. (three-awns) (nomenclature follows Kearney and Peebles 1951).

Sixteen sample sites $(15 \times 15 \mathrm{~m})$, all on the same ecological site, were selected to represent the diversity of plant communities and site stabilities that could occur on the site. Selection included evaluation of characteristics that were mainly responsible for influencing the erosional stability of the plant community. Plant composition within sample sites was chosen to be as uniform as possible to restrict internal variation. The sample sites were located within $300 \mathrm{~m}$ of each other to minimize the differences in soil and rainfall. One hundred quadrats were located on a systematic grid with 10 transects of 10 quadrats each, spaced $1.5 \mathrm{~m}$ apart within each sample site. A nested frame with 3 quadrat sizes ( 40 $\times 40 \mathrm{~cm}, 20 \times 20 \mathrm{~cm}$, and $10 \times 10 \mathrm{~cm}$ ) was used in sampling. Data were collected in the winter of 1991 and the summer of 1992. The winter sampling followed a dry summer growing season (118 $\mathrm{mm}$ of precipitation) and represented the site at an apparently low level of site stability (high risk of accelerated erosion due to minimal canopy and ground surface cover). The site was re-evaluated during the late summer of 1992 following above average precipitation $(238 \mathrm{~mm})$ and represented the site at an increased level of site protection (i.e., increased stability due to increased canopy and ground cover) compared to the winter sampling period.

Percent ground cover was determined by visually estimating the percent of basal vegetation, litter, rock ( $>2 \mathrm{~mm}$ ), and bare ground in each of the $40 \times 40 \mathrm{~cm}$ quadrats. The dry-weight-rank method of t'Mannetje and Haydock (1963) was used to estimate species composition by weight of perennial plants. Annual plants were not included in the sampling procedure due to their scarcity. The comparative-yield method of Haydock and Shaw (1975) was used to estimate total standing biomass with a ranking for each 40 $\times 40 \mathrm{~cm}$ quadrat. The point-centered-quarter method was used on each quadrat (total of 400 distance measurements per sample site) to obtain the average distance to the nearest perennial plant and to derive plant density for each sample site (Bonham 1989). Since measuring distance to the nearest perennial plant was time consuming, data on the frequency of quadrats with no rooted perennial plant was evaluated as a possible substitution for distance to the nearest perennial plant. Three quadrat sizes $(10 \times 10,20 \times$ $20,40 \times 40 \mathrm{~cm}$ ) were used to determine the best size, because frequency is a function of quadrat size.

A Site Stability Rating was estimated for each nested quadrat on a scale of 1 to 5 (Fig. 1) as an integer. The Site Stability Rating is a subjective rating procedure developed to determine if quadrats could be used to quantify the mean stability within a sample site. The Site Stability Rating descriptions were adapted from the Region 3 Range Analysis Forest Service Handbook (USDA-U.S. Forest Service 1970). They were based on the amount and patchiness of ground cover, and evidence of past soil movement. An average Site Stability Rating for the sample site was determined from each quadrat size.

Sediment yield was predicted for each sample site using the WEPP single event model (Version 93.3)(Laflen et al. 1991) with the vegetation parameters of distance to nearest perennial plant (m), percent rock and litter cover, and standing biomass $\left(\mathrm{kg} / \mathrm{m}^{2}\right)$. The WEPP model partitions soil erosion into rill and interrill erosion. Interrill erosion is a function of raindrop splash detachment. The amount of soil erosion from splash detachment is a function of rainfall intensity and amount of bare ground (Lane and Nearing 1989). Rill erosion is a function of velocity of the water and the sediment concentration within the water. Rilling and/or detachment of soil particles by concentrated flow is a function of the hydraulic shear force of the water. The hydraulic shear of the flowing water is inversely proportional to the hydraulic roughness of the surface and velocity of the water. Hydraulic roughness on rangelands within the WEPP model are estimated as a function of rock, litter, basal cover, standing biomass, random roughness, and soil texture (Weltz et al. 1992).

It was hypothesized that the storm intensity required to initiate rilling (a threshold increase in erosion rate) might be a way to identify the Site Conservation Threshold for rangelands. Those that rilled with a 10-year storm or less would be below the Site Conservation Threshold, those that rilled with a 25 -year storm might be borderline, and those that rilled only with a 50-year storm or greater would be above the Site Conservation Threshold. The six-hour rainfall event with return frequencies of $5,10,25$, 50 , and 100 years were used to estimate the effects of storm size on predicted soil erosion.

The hypothesized relationship of the six-hour, 10, 25, and 50year return frequencies storms to the health of rangeland ecosys- 


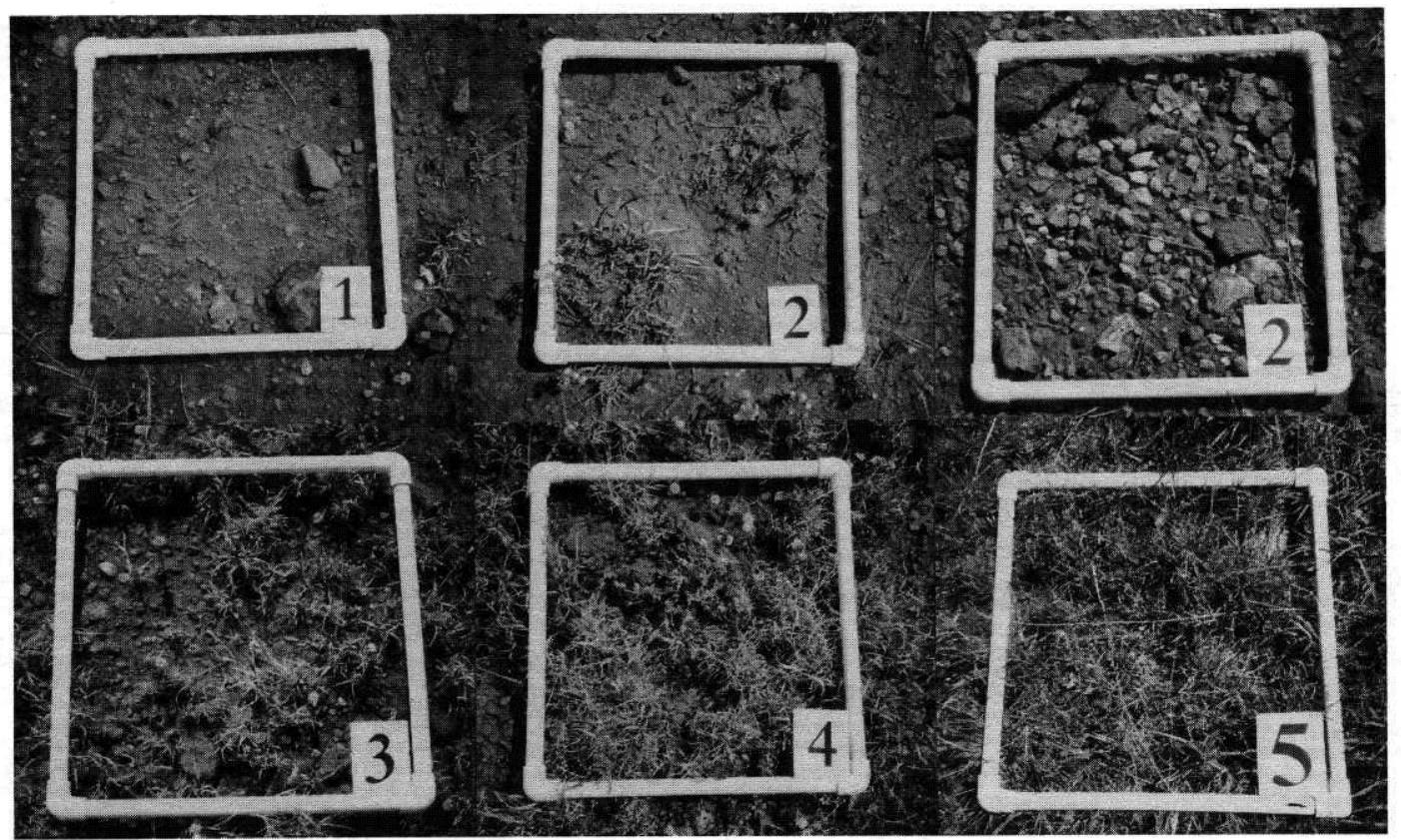

Fig. 1. Sample Site Stability Ratings for a clay loam upland rangeland site in the winter. 1) Plant cover and litter sparse, patchy, and definitely not effective in preventing soil movement. Bare spaces frequent, commonly coalesced with a definite runoff pattern; large bare spaces common. Erosion pavement may be well developed in bare spaces. Soil movement prominent. Majority of plants pedestaled. 2) Intermediate between 1 and 3. 3) Plant cover and litter thin or discontinuous and not well distributed. Bare spaces often coalescing but with no continuous runoff pattern, large spaces less common than small ones. Soil movement discernible on less than half the area. Occasional Pedestaling and close to bare spaces. 4) Intermediate between 3 and 5. 5) Plant cover and litter well distributed; appears effective in protecting the soil. Bare spaces small, well dispersed, occasionally coalescing. No erosion pavement. Soil movement none or very slight and patchy. Pedestaling rare and close to bare spaces.

tems were selected based on the following criteria. The selection of event duration (6-hours) was chosen to reflect the dominance of summer convective thunderstorms on soil erosion in the southwest in contrast to longer duration and lower intensity winter frontal storms (Renard et al. 1993). The return frequencies of 10, 25 , and 50-years were chosen to reflect the interaction of soil properties, land-use, and soil erosion. Based on work by Osborn (1984), Osborn and Goodrich (1993), and Renard et al. (1993) it was hypothesized that return frequencies of the 2 and 5-year event would often not generate sufficient overland flow to initiate rilling for many upland rangeland soils. The selection of the 10 , 25 , and 50-year return frequencies was based on the assumption that, at these rates, changes in land-use or management practices could alter the vegetation and surface soil conditions enough to influence protection from rilling. The 100 -year return event was not selected because for most arid and semi-arid ecosystems severe erosion will naturally occur because of lack of adequate precipitation to produce vegetation to protect the soil surface from these episodic events (Branson et al. 1981).

Total rainfall depth $(\mathrm{mm})$ for the six-hour, 5, 10, 25, 50, and 100 -year return frequency storms were $43,60,76,89$, and 108 , respectively. Maximum peak $10 \mathrm{~min}$. rainfall intensity $(\mathrm{mm} / \mathrm{hr})$ for the six-hour, $5,10,25,50$, and 100-year return frequency storms were $45,75,106,137$, and 199 , respectively. Soil characteristics, initial soil moisture, and slope variables were constant for all sample sites. Soil parameters of bulk density $\left(\mathrm{g} \mathrm{cm}^{-3}\right)$, soil texture [sand and clay (\%)], and organic matter (\%), were parameterized from data supplied by the Soil Conservation Service (Hendricks 1985). The erosion (interrill erodibility, rill erodibility, and critical shear stress) and hydrologic (effective hydraulic conductivity) parameters were estimated with the default equa- tions of the WEPP model (Lane and Nearing 1989). Soil moisture was initialized at $90 \%$ of saturation. Model outputs of interest were runoff volume $(\mathrm{mm})$ and sediment yield (ton/ha). The 25year storm event was used for further analysis because of its hypothesized "currently functioning-but at risk to degradation" relationship to site stability.

The WEPP model is highly sensitive to changes in litter cover and standing biomass (Tiscareno-Lopez et al. 1993). The minimum expected vegetation and rock cover (\%) should be used to define the Site Conservation Threshold for long term sustainability of the site. This conservative approach may result in some sites substantially exceeding the minimum canopy and ground cover needed to prevent soil erosion during years with above average growing season precipitation.

To evaluate the sensitivity of predicted erosion to plant density, three sample sites $(2,5$, and 9$)$ were used. All other WEPP model parameter values for the 25 -year storm event were held constant. These three sample sites were chosen because they represent the spectrum of diversity within the rangeland site of sediment yield; highly susceptible (5), moderately susceptible (9), and slightly susceptible (2). Sediment yield was predicted while varying distance between plants from $0.04 \mathrm{~m}$ to $100 \mathrm{~m}$. Correlation coefficients $(\mathrm{P} \leq 0.95)$ were used to demonstrate the interrelationships between ground cover, standing biomass, and distance to the nearest perennial plant (Cochran 1977). Non-linear regression techniques were employed to determine if a threshold of site stability could be determined based on estimated sediment yield from the WEPP model. The relationship of the Site Stability Rating and estimated sediment yield for the site was examined using non-linear regression techniques. The independent variables measured for use in linear and non-linear regression analy- 
ses were: percent ground cover (basal vegetation, litter, rock, and bare ground), standing biomass, distance to the nearest perennial plant, and frequency of quadrats having no rooted perennial plant. Estimated sediment yield and the Site Stability Rating were used as dependent variables.

\section{Results}

The predicted sediment yield varied considerably among sample sites when the vegetation data collected during the winter of 1991 were used (Fig. 2a). As storm intensity increased, runoff, peak discharge, and sediment yield increased (Figs. 2 and 3). There was a sharp increase in predicted erosion rates when rilling was initiated by the WEPP model. Five sample sites initiated rilling with the 10-year storm intensity, 8 sample sites started rilling at the 25 -year storm intensity, 2 rilled with the 100 -year storm, and one did not rill at the 100-year, 6-hour storm event. Simanton et al. (1991) reported that rilled plots produced approximately 3.3-3.4 times the average erosion rates as comparably sloped nonrilled rangeland areas.

When vegetation data (biomass, litter, and rock) collected during the summer of 1992 were used to parameterize the WEPP model, the results were substantially different from those obtained with the winter data from 1991 (Fig. 2b). Rilling did not
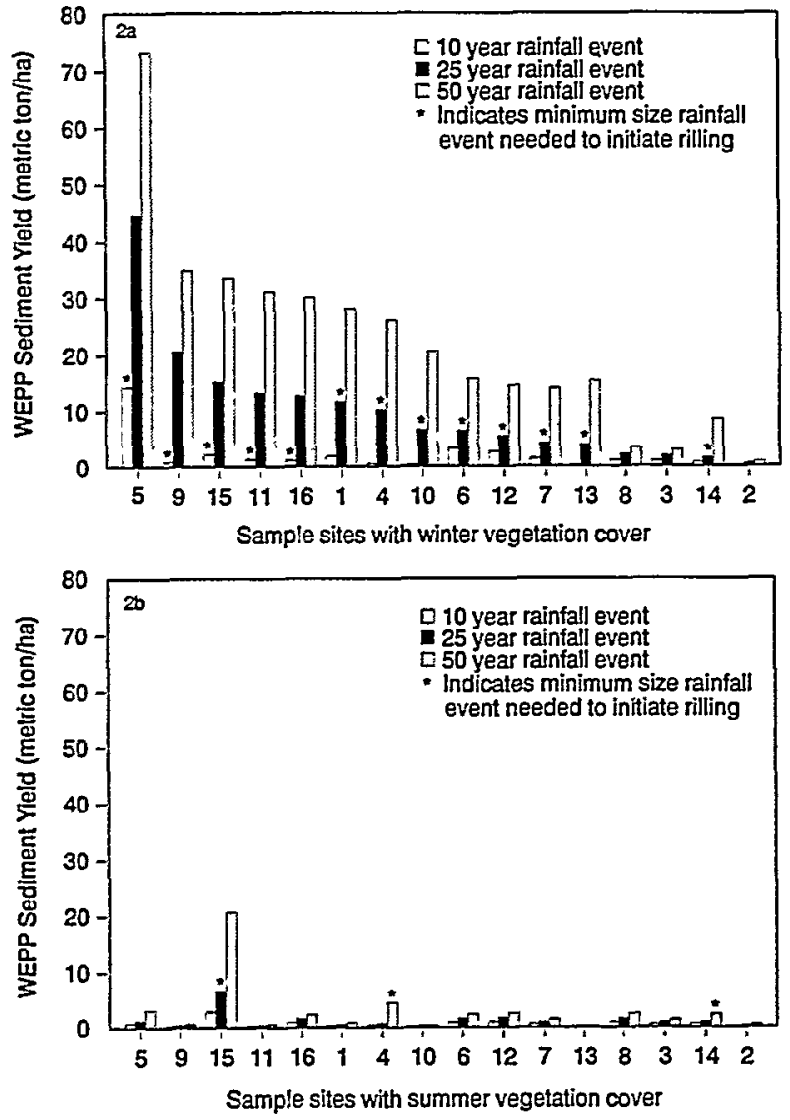

Fig. 2. WEPP model predicted sediment yield (ton $\mathrm{ha}^{-1}$ ) for the winter sampling (2a) and the summer sampling (2b). Sample sites are arrayed in order of decreasing winter erosion for the 25-year storm event. occur with a 10-year storm for any sample site, only one sample site rilled with a 25 -year storm and 2 with a 50 -year storm. The reduction in type and amount of soil erosion was attributed to the change in biotic characteristics of the site. The principal changes between the 2 sampling periods were the increases in litter and standing biomass, because of the time of year and doubling of rainfall during the summer 1992 growing season as compared to the winter of 1991 (Table 1).

No significant differences were found in basal vegetation cover between winter and summer except on sample site 12, which was predominately curly mesquite. The major land surface characteristic that changed between the winter and summer sampling were litter biomass, standing biomass, and bare ground. Litter increases ranged from 4 to $243 \%$, standing biomass increases ranged from 8 to $107 \%$, and bare ground decreases ranged from 0 to 137\%. The winter vegetation and cover data were used for further analysis and interpretation, since they represented the minimum ground cover and standing biomass evaluated during the study.

The subjective Site Stability Rating was highly correlated to basal cover $(r=0.91)$, litter cover $(r=0.79)$, and standing biomass $(r=0.94)$. The high correlation between cover, litter, and standing biomass and Site Stability Rating was expected as they are used to define the different classes in the Site Stability Rating. There was a significant relationship between the Site Stability Rating and the sediment yield predicated by the WEPP model.
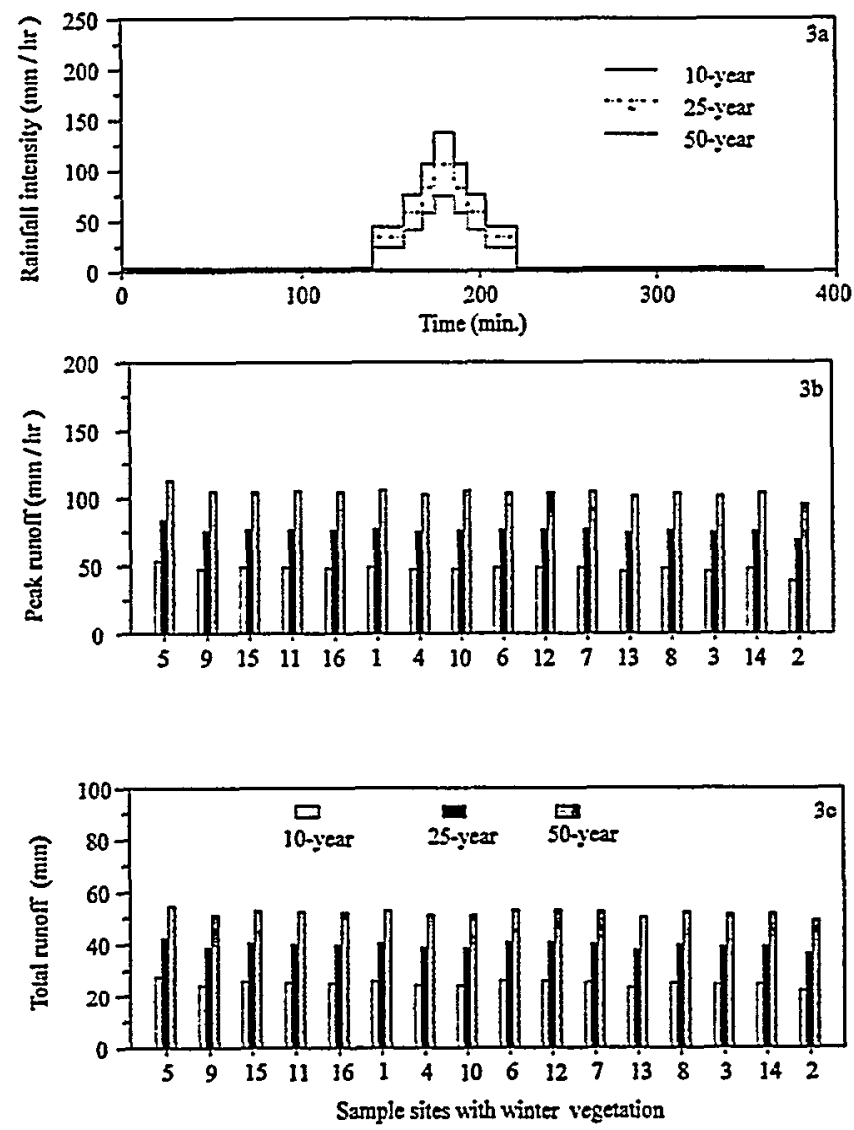

Fig. 3. WEPP model predicted rainfall intensity $\left(\mathrm{mm} \mathrm{hr}^{-1}\right)$ (3a), peak runoff rate $\left(\mathrm{mm} \mathrm{hr}^{-1}\right)(3 \mathrm{~b})$, and total runoff volume (mm) (3c) for sample sites with winter vegetation. 
Table 1. Vegetation characteristics for winter 1991 and summer 1992 sampling periods, ordered from least to most stable, based on the Site Stability Rating.

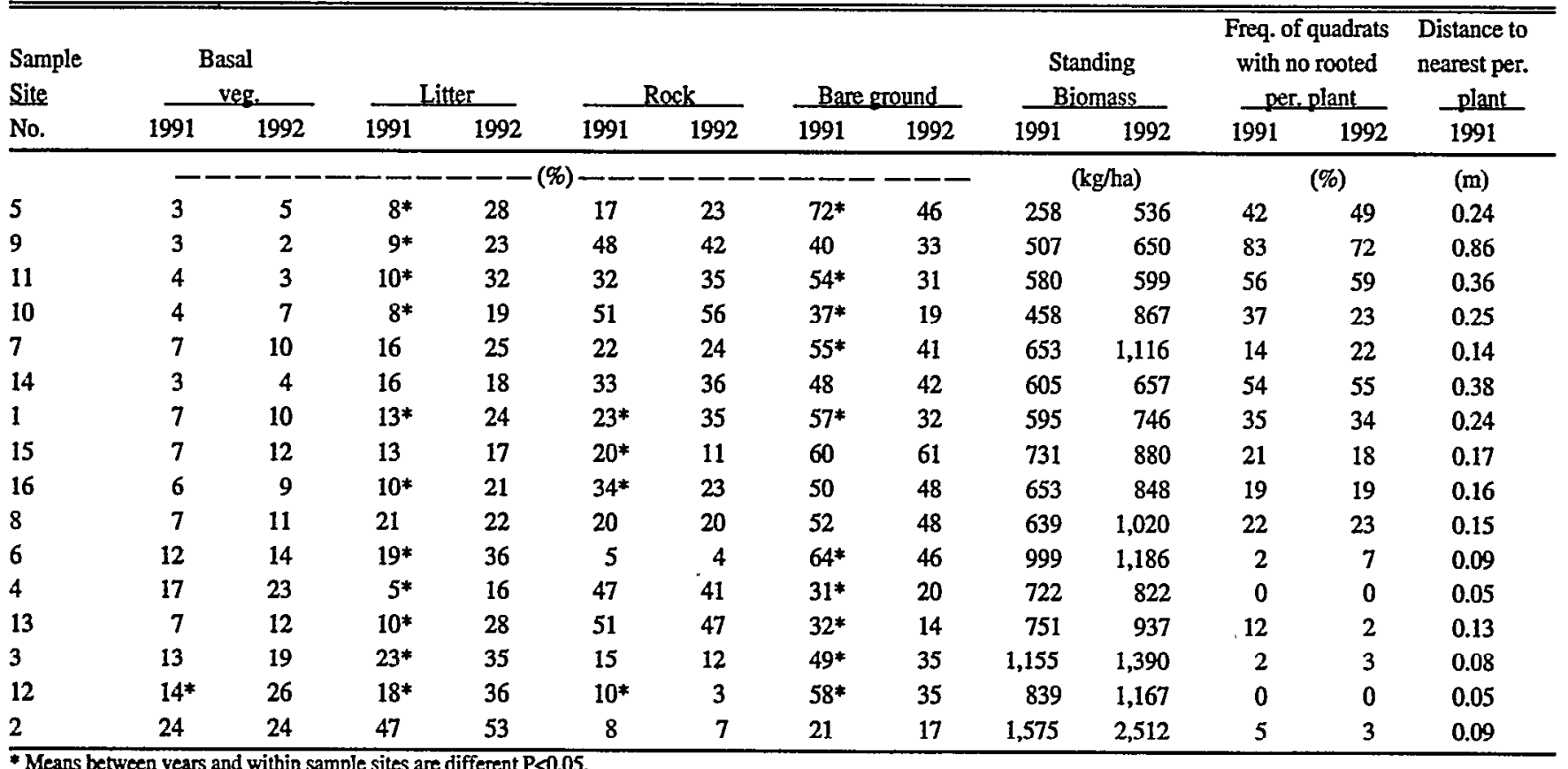

Quadrat size had little effect on the average Site Stability Ratings for a sample site and the average Site Stability Ratings for the three quadrat sizes $(10 \times 10,20 \times 20$, and $40 \times 40 \mathrm{~cm})$ were highly correlated ( $r>0.93$ ). Due to the lack of Site Stability Rating difference between quadrat sizes, results for the $20 \times 20$ $\mathrm{cm}$ quadrat size only will be presented.

A threshold in accelerated erosion rates occurred in the WEPP model when distance between plants exceeded $0.34 \mathrm{~m}$ for sample sites 5 and 9 (Fig. 4). Distance to nearest perennial plant did not affect rill formation regardless of canopy and ground cover once distance between plants exceeded $5 \mathrm{~m}$. The large quantity of litter and standing biomass on sample site 2 resulted in the applied hydraulic shear force being less than the critical shear force necessary to initiate rilling. Therefore, this site was stable for all distances evaluated. Ground surface cover was not sufficient to prevent hydraulic shear force from exceeding critical shear force for sample sites 5 and 9 and rilling was initiated. The number and width of rills across the landscape was in part a function of plant density.

The non-linear regression analysis demonstrates an exponential increase in predicted sediment yield as the Site Stability Rating decreases (Fig. 5). In an effort to establish some objective means of determining a threshold value for the Site Stability Rating, soil loss tolerance factors (T-values) were used. The T-values are currently estimated to vary from $4,500 \mathrm{~kg} / \mathrm{ha} / \mathrm{yr}$ ( 1 ton/acre/yr) on very shallow soils to $11,200 \mathrm{~kg} / \mathrm{ha} / \mathrm{yr}$ ( 5 ton/acre/year) on deep soils (USDA-SCS 1992). The Whitehouse soil found on the clay-loam upland rangeland site has a T-value of $11,200 \mathrm{~kg} / \mathrm{ha} / \mathrm{yr}$ (USDA-SCS 1976). The threshold value for this site (2.5) was found by solving the fitted relationship (Fig. 5) between estimated sediment yield and Site Stability Rating for a T-value of $11,200 \mathrm{~kg} / \mathrm{ha} / \mathrm{yr}$. For other sites with either a different T-value or biotic conditions the threshold value could change. More research will need to be conducted in other climatic and biotic regions to establish the range of threshold values and its applicability for these areas.

The percent of exposed bare soil was poorly correlated to Site Stability Rating $\left(r^{2}=0.31\right)$. Standing biomass, basal vegetation cover, distance to the nearest perennial plant, and frequency of quadrats with no rooted perennial plant showed the highest correlations to the Site Stability Rating (Fig. 6). Standing biomass explained the most variation in the Site Stability Rating of the 4 vegetation attributes evaluated. Standing biomass during the winter was significantly correlated to the Site Stability Rating $\left(r^{2}=\right.$ 0.87 ) (Fig. 6a). The threshold Site Stability Rating of 2.5 corresponds to $750 \mathrm{~kg} / \mathrm{ha}$ of standing biomass, indicating that sample sites having less biomass are below the Site Conservation Threshold. Basal vegetation cover was significantly correlated to the Site Stability Rating $\left(r^{2}=0.78\right)$. A basal cover value of $8 \%$ corresponds to the threshold Site Stability Rating of 2.5 (Fig. 6b).

Distance to the nearest perennial plant (Fig. 6c) was negatively correlated with the Site Stability Rating. As distance between plants increased the Site Stability Rating decreased. The threshold Site Stability Rating of 2.5 corresponded to a distance to the nearest perennial plant of $15 \mathrm{~cm}\left(\mathrm{r}^{2}=0.62\right)$. The threshold value for distance to the nearest perennial plant $(15 \mathrm{~cm})$ was below that indicated by the sensitivity analysis $(34 \mathrm{~cm})$. The co-dependence between biotic variables and the way WEPP calculates rill density is one reason for the difference. We found, with observed data, that as distance to the nearest perennial plant increased there was a positive correlation with increasing rock cover $\left(r^{2}=0.50\right)$ and a significant negative correlation with standing biomass and basal cover $\left(r^{2}=0.90\right.$ and 0.81 , respectively). The WEPP model cannot currently use these types of co-dependent relationships. WEPP calculates the number of potential rills (concentrated flow paths) based on the distance between plants. The calculation of potential rill density is independent of standing biomass, basal cover, and other biotic and abiotic factors. 


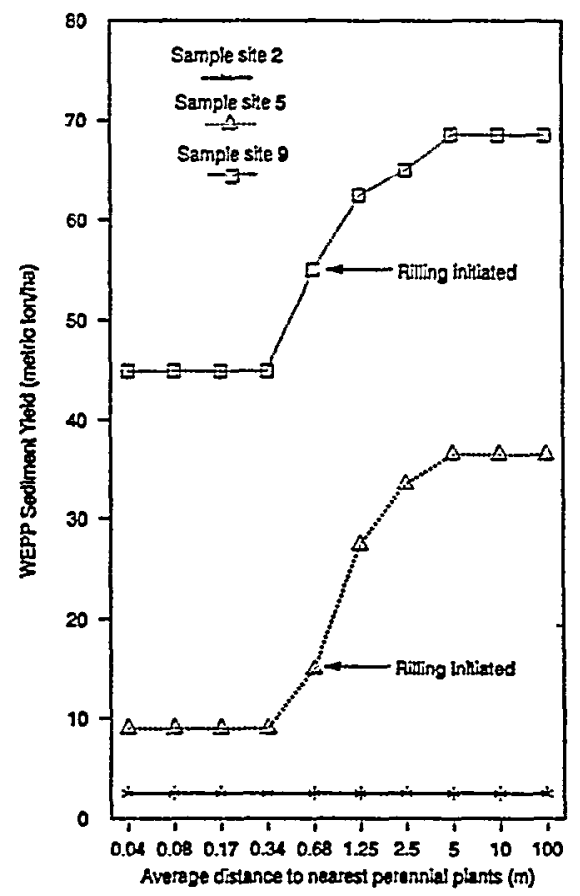

Fig. 4. WEPP model sensitivity to the average distance to the nearest perennial plant (m).

The frequency of quadrats that had no rooted perennial plant was highly correlated with distance to nearest plant, and thus might be employed as an objective surrogate measure for plant spacing in the field. The frequency of bare quadrats $(20 \times 20 \mathrm{~cm})$ was negatively correlated with the Site Stability Rating $\left(\mathrm{r}^{2}=\right.$ 0.58 ) (Fig. 6d). The threshold Site Stability Rating (2.5) corresponds to a $13 \%$ frequency of quadrats having no perennial plant rooted within them. Frequency of bare quadrats $(40 \times 40 \mathrm{~cm})$ did not show a good relationship (high $r^{2}$ ) to the Site Stability Rating. This was caused by a significant number of 0 values for the frequency of quadrats with no rooted perennial plant. The technique of estimating frequency with no rooted perennial plant had the smallest coefficient of determination of the biotic variables evaluated. The frequency technique does have some advantages over estimating standing biomass, basal cover, and distance between perennial plants. The relationship of frequency with no rooted perennial plants within the $20 \times 20 \mathrm{~cm}$ quadrats to Site Stability Rating was consistent with both the winter and summer data and the frequency technique requires less time and expertise to estimate.

\section{Discussion}

The focus of this work was to develop the methodology and techniques necessary to define the limits (Site Conservation Threshold) between the categories of satisfactory and unsatisfactory rangelands. The basic concept behind the Site Conservation Threshold is the development of stable indicator(s) for prediction of sustainable agricultural practices. The WEPP model is capable of providing a non-subjective, repeatable, method of estimating sediment yield that can be used to evaluate differences between management practices or land units to establish which are potentially sustainable.

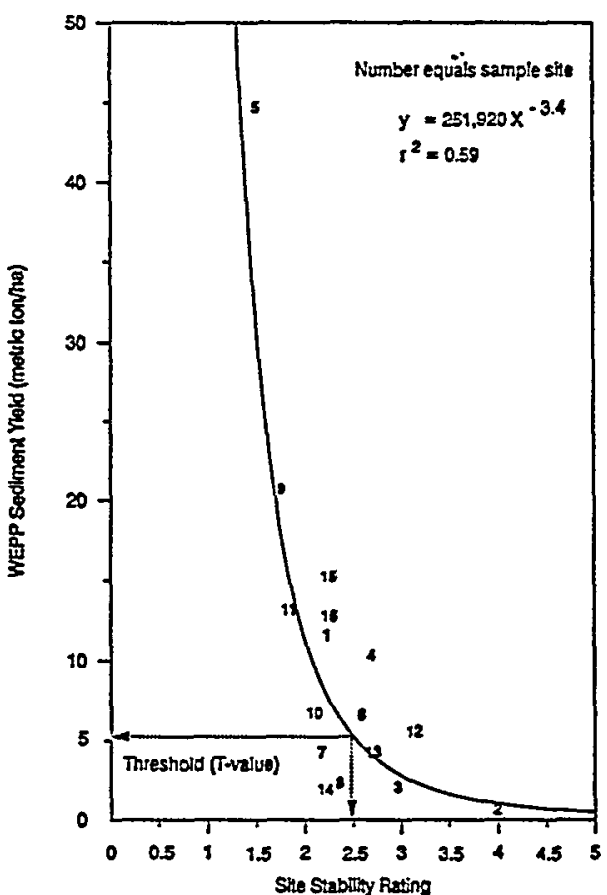

Fig. 5. A threshold relationship between the WEPP model predicted sediment yield (ton $\mathrm{ha}^{-1}$ ) and the Site Stability Ratings.

A limitation with this study is the lack of observed precipitation, runoff, and sediment yield data to evaluate the models predicted sediment yield relationships to the abiotic and biotic conditions evaluated here. However, the WEPP model has been evaluated for numerous rangeland situations in southern Arizona on the USDA-ARS Walnut Gulch Experimental Watershed near Tombstone, Ariz. The model has been shown to give good results in predicting runoff volume and peak discharge in the southwest. Stone et al. (1992) evaluated the hydrologic component of the WEPP model for a semi-arid desert shrub area on the Walnut Gulch Experimental Watershed and concluded that the model did a good job in fitting observed and predicted runoff volume and peak discharge $\left(r^{2}=0.91\right)$. Tiscareno-Lopez (1994) evaluated the model on a semi-arid desert grassland watershed $(1.3 \mathrm{ha})$ with similar vegetation, soil, and slope characteristics as this study and concluded that the model could accurately predict runoff volume and peak discharge. Data from the USDA WEPP rangeland ficld experiments (see Simanton et al. 1991) were used to test the model's ability to predict sediment yield at 16 locations in the western United States (Kidwell 1994). Kidwell (1994), working on a different semi-arid grassland area within the Walnut Gulch watershed, reported that for an area with similar soils and vegetation as this study, that the WEPP model predicted runoff volume and peak discharge were within $2 \%$ of the observed data and that predicted sediment yield was within $16 \%$ of observed sediment yield. They all concluded that the WEPP model was capable of reliably predicting runoff and sediment yield when appropriately parameterized.

Further research will need to focus on the number of replicates, size of area, and topographic position of the area being evaluated to fully develop the Site Conservation Threshold concept for rangelands. Dunne et al. (1993) reported that on long hillslopes the downslope increase in flow depth in concentrated flow channels progressively inundates more permeable vegetated coppice 

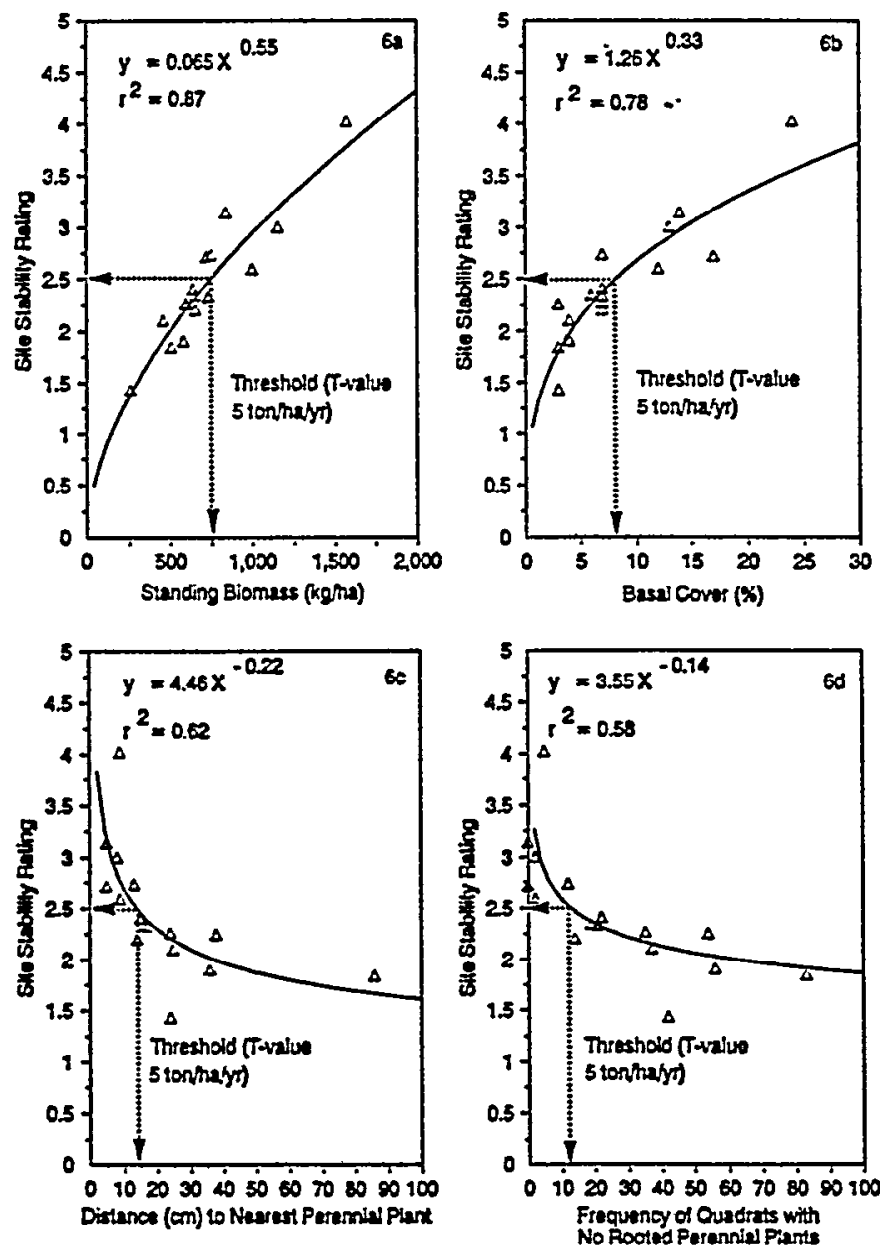

Fig. 6. Threshold relationships between Site Stability Ratings and winter vegetation biological characteristics of 5a) standing biomass, 5 b) basal cover, $5 c$ c) distance to the nearest perennial plant, and $5 \mathrm{~d}$ ) frequency of quadrats with no rooted perennial plant.

dunes so that hydraulic conductivity of a greater proportion of the surface is raised to its saturated value. This results in increased flow velocity and potential increases in sediment detachment through the rilling process in the downslope direction. Lane et al. (1995) reported that varying slope length and steepness, as well as canopy and ground cover in the downslope direction can significantly alter the sediment deposition rate and thus sediment yield on rangelands. They concluded that incorporating spatially varying canopy and ground cover in the downslope direction in estimating erosion is mandatory if gross distortions in sediment yield are to be avoided.

One advantage of using the WEPP model to calculate the apparent sediment yield from a hillslope is its ability to account for variable soil and cover conditions in the downslope as well as across the slope directions. This allows for identification of areas along the hillslope that are actively eroding in excess of the Site Conservation Threshold that would not be detectable if other erosion prediction technology were used. A second advantage of the WEPP model is in eliminating the subjectivity involved in locating sample sites on the hillslope to account for spatially varying surface conditions. The WEPP model can estimate soil loss from the entire hillslope. This eliminates the requirement of developing methods to account for varying soil loss along the hillslope. Slope length limits for applicability for the Site Conservation Threshold have not been precisely defined. The minimum length of area to be considered is approximately from the origin of overland flow to concentration of flow in a well defined channel. The preferred solution would be from the ridge top to the end of the hillslope.

Site Conservation Thresholds were found for standing biomass ( $750 \mathrm{~kg} / \mathrm{ha})$, basal cover (8\%), average distance between perennial plants $(15 \mathrm{~cm})$, and frequency of quadrats with no rooted perennial plant (13\%) for a semi-arid desert grassland in Southern Arizona. Estimated basal cover was the best single indicator of site stability of those evaluated in this study. Basal cover varied with season and weather conditions, but was much less sensitive to these short term seasonal climatic variation and grazing pressure than was standing biomass or litter. Standing biomass at any date within a year is highly dependent on effective precipitation within the growing season, current weather conditions, relationship to livestock grazing cycles and stocking rates, and the decomposition of biomass. The amplitude in standing and litter biomass over time due to climate and land management practices will result in significant changes in estimated sediment yield. Therefore, the site will alternate above and below the Site Conservation Threshold based solely on sampling date.

A conservative approach is to sample when the least amount of vegetation is expected prior to the time of highest probability of intense thunderstorm activity. The critical time in southern Arizona for sampling is in early June prior to the onset of the monsoon season in July and August. If the site is stable with no indication of accelerated erosion under these conditions, then the soil resources will be retained and a sustainable ecosystem should be achieved. Measurements would need to be site specific. The same thresholds cannot be applied to all ecological sites because of the complex interactions that occur.

The Site Conservation Rating technique is not intended to replace the WEPP model for estimating soil erosion on rangelands. However, the data required to parameterize the WEPP model are considerable and costly to collect. The Site Conservation Rating method is being proposed for rapid assessment or inventory of rangelands. If the Site Conservation Rating for a pasture, landscape or watershed is below the threshold then a detailed assessment of the area should be performed to determine if the site is actually below the threshold with the WEPP model. The WEPP model can be used to evaluate alternative management scenarios (change in season of use, stocking rate, or kind of animal, etc.) to determine which have the highest potential for preventing future degradation and or recovery of the site.

\section{Literature Cited}

Blackburn, W.H., R.W. Knight, and M.K. Wood. 1982. Impact of grazing on watersheds: A state of knowledge. Texas Agr. Exp. Sta. MP 1496. College Station, Tex. 32 pp.

Bonham, C.D. 1989. Measurements for terrestrial vegetation. John Wilcy \& Sons. N.Y.

Branson, F.A., G.F. Gifford, K.G. Renard. R.F. Hadley. 1981. Rangeland hydrology. Rangeland Science Series 2nd Edition, Society for Range Management, Denver, Colo. Kendall/Hunt Publishing.

Cochran, W.G. 1977. Sampling techniques. John Wiley \& Sons. N.Y.

Costin, A.B. 1980. Runoff and soil and nutrient losses from improved pasture Ginninderra, Southern Tablelands. New South Wales. Australian J. Agr. Res. 31:533-546.

Costin, A.B., D.J. Wimbush, and R.N. Cromer. 1960. Studies in catchment hydrology in the Australian Alphs II surface runoff and soil loss. CSIRO Division of Plant Industry, Tech. Paper No. 14. 
Dunne, T., W. Zhang, and R. F. Aubry. 1993. Effects of rainfall, vegetation, and microtopography on infiltration and runoff. Water Res. Res. 27: 2271-2285.

Ellison, L. 1949. The ecological basis for judging condition and trend on mountain range land. J. Forestry 47(10):786-795.

Gifford, G. F. 1984. Vegetation allocation for meeting site requirements. pp. 35-116. In: NAS/NRC. Developing Strategies for Rangeland Management. Westview Press.

Gifford, G.F. and R.H. Hawkins. 1978. Hydrologic impact of grazing on infiltration: A critical review. Water Resource Res. 14(2):305-313.

Haydock, K.P., and N.H. Shaw. 1975. The comparative yield method for estimating the dry matter yield of pasture. Australian J. of Exp. Agr. Animal Husb. 15:663-670.

Hendricks, D. M. 1985. Arizona soils. Univ. of Arizona Press.

Kearney, T. H. and R. H. Peebles. 1951. Arizona Flora. Univ. of California Press, Berkley.

Kidwell, Mary R. 1994. Distribution of ground cover and its effect on runoff and sediment yield in the WEPP model. M.S. Thesis, The University of Arizona, Tucson.

Laflen, J.M., L.J. Lane, and G.R. Foster. 1991. WEPP: A new generation of erosion prediction technology. J. Soil Water Cons. 46:30-34.

Lane, L. J., M. H. Nichols, and J. R. Simanton. 1995. Spatial variability of cover affecting erosion and sediment yield in overland flow. In: Effects of scale on interpretation and management of sediment and water qualilty. International Association. Hydrological Sciences. (in Press).

Lane, L.J. and M.A. Nearing (editors). 1989. USDA-water erosion prediction project: hillslope profile model documentation. NSERL Report No.2. W. Lafayette, Indiana.

Lang, R.D. 1979. The effect of ground cover on surface runoff and soil loss from experiments plots. J. Soil Conserv. Service of New South Wales. 35:108-114.

Marston, R.B. 1952. General cover requirements for summer storm runoff control on Aspen sites in Northern Utah. J. Forestry. 50:303-307

Moore, T.R., D.B Thomas, and R.G. Barber. 1979. The influence of grass cover on runoff and soil erosion from soils in the Machakos area, Kenya. Tropical Agr. 50:339-334.

NOAA (National Oceanic and Atmospheric Administration). 1991. Climatological Data Annual Summary, Arizona. Vol 95, No. 13.

Noble, E.L. 1965. Sediment reduction through watershed rehabilitation. Misc. Publ. 970, U.S.D.A., 114-123.

NRC (National Research Council), Committee on Rangeland Classification. 1994. Rangeland health: new methods to classify, inventory and monitor rangelands. National Academy Press, Washington, D.C.

Orr, H.K. 1970. Runoff and erosion control by seeded and native vegetation on a forest burn: Black Hills, South Dakota. USFS Res. Paper RM-60. 12 pages.

Osborn, H. B. 1984. Storm-cell properties influencing runoff from small watersheds. Trans. Res. Record. 922: 24-32.

Osborn, H. B. and D. C. Goodrich. 1993. Characterization of thunderstorm rainfall for hydrologic modeling. Pgs. 409-415. In: Management of Irrigation and Drainage Systems. ASCE.

Packer, P.E. 1951. An approach to watershed protection criteria. J. Forestry 49:635-644.

Renard, K.G., L. J. Lane, J. R. Simanton, W. E. Emmerich, J. J. Stone, M. A. Weltz, D. C. Goodrich, and D. S. Yakowitz. 1993. Agricultural impacts in an arid environment: Walnut Gulch studies. Hydrological Science and Technology. 9:145-190.

Simanton, J. R., M. A. Weltz, and H. D. Larsen. 1991. Rangeland experiments to parameterize the water erosion prediction project model: vegetation canopy cover effects. J. Range Manage. 44: 276-282.

Smith, E. L. 1988. Successional concepts in relation to range condition assessment. In: Vegetation science applications for rangeland analysis and management, Tueller, P.T. (ed). Kluwer Academic Publishers.
Smith, E. L. 1989. Monitoring concepts for rangelands. p. 210-220. In: Volume 1: Conference Proceedings of the Global Natural Resource Monitoring and Assessments: Preparing for the 21st Century. September, 1989. Venice. Italy.

SRM (Society of Range Management), Range Inventory Standardization Committee. 1983. Guidelines and terminology for range inventories and monitoring. Soc. Range Manage. Denver, Colo.

SRM (Society of Range Management), Task Group on Unity in Concepts and Terminology. 1991. New direction in range condition assessment: Report to SRM Board of Directors. Soc. Range Manage. Denver, Colo.

Stone, J. J., L. J. Lane, and E. D. Shirley. 1992. Infiltration and runoff simulation on a plane. Trans. Am. Soc. Agric. Eng. 35:161-170.

Thurow, T.L., W.H. Blackburn, and C.A. Taylor, Jr. 1986. Hydrologic characteristics of vegetation types as affected by livestock grazing systems, Edwards Plateau, Texas. J. Range Manage. 39:505-509.

Tiscareno-Lopez, M., V.L. Lopes, J.J. Stone, and L.J. Lane. 1993. Sensitivity Analysis of the WEPP Watershed Model for Rangeland Applications I: Hillslope processess. Trans. Amer. Soc. Agr. Eng. 36: 1659-1672.

Tiscareno-Lopez, M. 1994. A bayesian-monte carlo approach to assess uncertainties in processed-based continuous simulation models. Ph.D. Thesis., The University of Arizona, Tucson.

t'Mannetje, L. and K.P. Haydock. 1963. The dry-weight rank method for the botanical analysis of pasture. J. British Grassl. Soc. 18:268-275.

USDA-SCS. 1976. Soil Loss Equation. Conservation Planning Note No. 11 - Arizona. Phoenix, Ariz.

USDA-SCS. 1988. Clay loam upland 12-16PZ range site description. Arizona Field Office.

USDA-SCS. 1992. National Soil Survey Interpretations Handbook. Washington D.C.

USDA-U.S. Forest Service. 1970. Range Environmental Analysis Handbook, Southwestern Region. 34.52,1-3.

USDI-BLM. 1993. Riparian area management. Tech. Rep. 1737-9. Denver, Colo.

Weltz, M.A. and M.K. Wood. 1986. Short duration grazing in Central New Mexico: Effect on sediment production. J. Soil and Water Conserv. 41:262-266.

Weltz, M. A. A. B. Arslan, and L. J. Lane. 1992. Hydraulic roughness coefficients for native rangelands. J. Irrig. and Drainage Eng. 118(5):776-790. 